\title{
ErbB2 copy number gain is associated with adverse outcome in canine mammary carcinoma
}

\author{
Kosei SAKAI ${ }^{1)}$, James Ken CHAMBERS ${ }^{2)}$, Kazuyuki UCHIDA ${ }^{2)}$, \\ Takayuki NAKAGAWA'), Ryohei NISHIMURA ${ }^{3)}$, Tomohiro YONEZAWA ${ }^{1)}$ and \\ Shingo MAEDA ${ }^{1) *}$ \\ 1)Department of Veterinary Clinical Pathobiology, Graduate School of Agricultural and Life Sciences, \\ The University of Tokyo, 1-1-1 Yayoi, Bunkyo-ku, Tokyo 113-8657, Japan \\ ${ }^{2)}$ Department of Veterinary Pathology, Graduate School of Agricultural and Life Sciences, The University of Tokyo, \\ 1-1-1 Yayoi, Bunkyo-ku, Tokyo 113-8657, Japan \\ 3) Department of Veterinary Surgery, Graduate School of Agricultural and Life Sciences, The University of Tokyo, \\ 1-1-1 Yayoi, Bunkyo-ku, Tokyo 113-8657, Japan
}

\section{J. Vet. Med. Sci.}

83(3): 370-377, 2021

doi: $10.1292 / j v m s .20-0483$

Received: 17 August 2020

Accepted: 29 December 2020 Advanced Epub:

19 January 2021
ABSTRACT. Copy number gain (CNG) and/or protein overexpression of ErbB2 have been observed in human breast cancer patients and are associated with poor prognosis. Similarly, ErbB2 overexpression has also been observed in canine mammary carcinoma; however, data on ErbB2 copy number is limited. The purposes of this study were to evaluate ErbB2 copy number in dogs with mammary carcinoma and to investigate associations of ErbB2 CNG with ErbB2 expression, histological and clinical characteristics, and survival. DNA samples were isolated from 59 formalinfixed paraffin-embedded canine mammary gland tissues (34 carcinoma, 14 adenoma, and 11 normal). Using a digital PCR assay, the ErbB2 copy number in these samples was determined as compared to a reference gene on canine chromosome 8. ErbB2 CNG was detected in 14/34 (41\%) carcinomas and 2/14 (14\%) adenomas. ErbB2 overexpression was observed in 3/34 (9\%) carcinomas but not in adenomas. Neither ErbB2 CNG nor ErbB2 overexpression were detected in the normal controls. There was no significant association of the ErbB2 CNG with histological and clinical characteristics such as age, neutered status, histological grade, tumor size, lymph node involvement, distant metastasis, and clinical stage in the dogs with mammary carcinoma. The presence of ErbB2 CNG, but not ErbB2 overexpression, was significantly related to the shorter overall survival. These findings suggest that ErbB2 CNG is a prognostic factor in dogs with mammary carcinoma.

KEY WORDS: copy number aberration, dog, ErbB2, mammary carcinoma, prognosis

ErbB2, also known as human epidermal growth factor receptor 2 (HER2), is a cell surface receptor tyrosine kinase belonging to the ErbB2 family (ErbB1-4). Under normal circumstances, ErbB2 is involved in cell proliferation, survival, angiogenesis, and migration [12]. A normal cell has 2 copies of ErbB2; however, in approximately $20-40 \%$ of human breast cancer patients, the gene is present in more than two copies, known as ErbB2 copy number gain (CNG) [4, 8, 16, 17, 22, 31]. ErbB2 CNG is caused by gene amplification and/or polysomy and leads to ErbB2 protein overexpression [16, 22]. Patients with CNG as well as protein overexpression of ErbB2 have shown poor prognosis [4, 8, 30, 31]. Apart from being a prognostic marker, ErbB2 is also important as a therapeutic target for human breast cancer. ErbB2-targeted therapies include the use of trastuzumab and lapatinib. Trastuzumab is an anti-ErbB2 humanized monoclonal antibody. Treatment with trastuzumab significantly improves 33-52\% of disease-free survival and $34-41 \%$ of overall survival in early human breast cancer patients [24, 32]. Lapatinib is a small-molecule tyrosine kinase inhibitor of ErbB2 [27,36]. Treatment with lapatinib has prolonged progression-free survival in human breast cancer patients who had progressed on trastuzumab monotherapy $[6,7]$. Given the prognostic and therapeutic implications, an assessment of ErbB2 level in a human breast cancer patient is crucial.

Canine mammary gland tumors account for approximately $50 \%$ of all tumors in female dogs [20]. Of these tumors, 41-53\% are malignant [3]. Several studies have proposed canine cases as a model of human breast cancer based on many similarities that

*Correspondence to: Maeda, S.: amaeda@mail.ecc.u-tokyo.ac.jp (Supplementary material: refer to PMC https://www.ncbi.nlm.nih.gov/pmc/journals/2350/) (O2021 The Japanese Society of Veterinary Science

This is an open-access article distributed under the terms of the Creative Commons Attribution Non-Commercial No Derivatives (by-nc-nd) License. (CC-BY-NC-ND 4.0: https://creativecommons.org/licenses/by-nc-nd/4.0/) 
have been reported between the two species $[1,18,25]$. ErbB2 protein overexpression has been observed in $18-48 \%$ of canine mammary carcinoma $[10,13,19,26,29]$, which was similar to that reported in human breast cancer $(15-30 \%)$ [14]. On the other hand, data on ErbB2 copy number in canine mammary carcinoma is limited. A previous study, using chromogenic in situ hybridization, has shown no ErbB2 CNG in canine mammary carcinoma [19]. However, the sample size of the study was too small $(n=6)$ to reach a conclusion. Another study, using digital PCR (dPCR), has shown that ErbB2 CNG was detected in 4/20 (20\%) canine mammary carcinoma [5]. To our knowledge, there is no study investigating whether ErbB2 CNG is associated with prognosis in dogs with mammary carcinoma.

In this study, we evaluated ErbB2 copy number in canine mammary carcinoma using a dPCR assay with formalin-fixed paraffinembedded (FFPE) tissues and compared these data with results of ErbB2 protein expression obtained from immunohistochemistry in the same specimens. Moreover, we investigated association of ErbB2 CNG with histological and clinical characteristics and survival in dogs with mammary carcinoma.

\section{MATERIALS AND METHODS}

\section{Samples}

A total of 59 FFPE canine mammary gland tissues (34 carcinoma, 14 adenoma, and 11 normal) were used in this study (Supplementary Table 1). Tissue samples of 11/11 normal, 8/14 adenoma, and 34/34 carcinoma were obtained from different individuals. Remaining adenoma tissues were obtained from four carcinoma cases included in this study and different udders of an adenoma case. Tissues of carcinoma and adenoma were surgically excised from clinical cases at the Veterinary Medical Center of The University of Tokyo from December 2009 to December 2015. The diagnoses were based on histopathological evaluation. Informed consent was obtained from dog owners for the use of clinical data and samples. This study did not reach the threshold for submission to a local ethical and welfare committee, since the collection and use of clinical data and samples were daily activities.

\section{Evaluation of histological and clinical characteristics}

Hematoxylin and eosin-stained specimens of the mammary carcinoma tissues were evaluated by two pathologists with Japanese College of Veterinary Pathologists board certification (J.K.C. and K.U.). Each specimen was classified and graded in accordance with a method proposed by Goldschmidt et al [11]. TNM classification and clinical stage at surgery were determined for each mammary carcinoma case based on medical records [21].

\section{DNA extraction and $d P C R$}

DNA was extracted from each tissue sample with QIAmp DNA FFPE Tissue Kit (QIAGEN, Hilden, Germany), according to the manufacturer's instructions. A dPCR assay established in our previous study was used for evaluating ErbB2 copy number [28]. Primers and TaqMan MGB probes of $E r b B 2$ and a reference gene were designed with Primer Express Software (Thermo Fisher Scientific, Waltham, MA, USA). The reference gene was designed within a region of canine chromosome 8 (CFA8). The region was relatively stable in canine mammary carcinoma, according to a previous study on genome aberrations [5]. The following primers and probes were used: ErbB2 forward, 5'-GTGGTGAGGCTGGTTTTCAGA-3' (Position: 26104529-26104549); ErbB2 reverse, 5'-CCTGTCCTCCCACCTCTTCAT-3' (Position: 26104469-26104489); ErbB2 probe, 5'-TAACCGCTAAGCAGTATGT-3' (Position: 26104494-26104512); CFA8 forward, 5'-TGCAGAGTTTGATTTGTTGTTTGAA-3' (Position: 76953717695395); CFA 8 reverse, 5'-TGGAAGAAGGTGCATTTTTCTGA-3' (Position: 7695315-7695337); CFA8 probe, 5'-AATGCCTTTGACCAGTGGGTAGCC-3' (Position: 7695347-7695370). The ErbB2 and CFA8 probes were labelled with 6-carboxyfluorescein (FAM) and 4,7,2'-trichloro-7'-phenyl-6-carboxyfluorescein (VIC), respectively. All the primers and probes were custom made at Thermo Fisher Scientific. PCR was performed using a QuantStudio ${ }^{\text {TM }}$ 3D Digital PCR system (Thermo Fisher Scientific), as described previously $[15,28]$. In brief, each $15 \mu 1$ reaction mixture contained 2X QuantStudio ${ }^{\mathrm{TM}}$ 3D Digital PCR Master Mix v2 (Thermo Fisher Scientific), $900 \mathrm{nM}$ of each primer, $200 \mathrm{nM}$ of each probe, and $20 \mathrm{ng}$ of genomic DNA for FFPE canine mammary gland tissues. The PCR reaction mixtures were then loaded onto a QuantStudio ${ }^{\text {TM }} 3 \mathrm{D}$ Digital PCR 20K Chip v2 (Thermo Fisher Scientific) using a QuantStudio ${ }^{\text {TM }}$ 3D Digital PCR Chip Loader (Thermo Fisher Scientific). The 20K chip contained 20,000 wells, inside which DNA was randomly and uniformly distributed. Amplification was carried out using ProFlex ${ }^{\mathrm{TM}}$ $2 \times$ Flat PCR System (Thermo Fisher Scientific) under the following conditions: denaturation at $96^{\circ} \mathrm{C}$ for $10 \mathrm{~min} ; 39 \mathrm{cycles}$ at $60^{\circ} \mathrm{C}$ for $2 \mathrm{~min}, 98^{\circ} \mathrm{C}$ for $30 \mathrm{sec}, 60^{\circ} \mathrm{C}$ for $2 \mathrm{~min}$, after which the temperature was maintained at $10^{\circ} \mathrm{C}$. Subsequently, the PCR chip was loaded on a QuantStudio ${ }^{\text {TM }}$ 3D Digital PCR Instrument (Thermo Fisher Scientific). The positive and negative plots were counted,

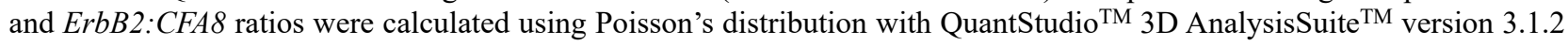
(Thermo Fisher Scientific, Fig. 1).

\section{Immunohistochemistry for ErbB2}

Immunohistochemistry for ErbB2 was performed as described previously [34]. Briefly, $4 \mu \mathrm{m}$ sections were deparaffinized, rehydrated, and treated with 3\% hydrogen peroxide-methanol at room temperature for 5 min and then heated in a water bath at $98^{\circ} \mathrm{C}$ for $40 \mathrm{~min}$ in target retrieval solution ( $\mathrm{pH}$ 9.0, Dako, Glostrup, Denmark). After being cooled for an hour, the sections were washed in Tris-buffered saline (TBS) and then incubated in $8 \%$ skimmed milk-TBS at $37^{\circ} \mathrm{C}$ for 40 min. The sections were incubated with rabbit polyclonal anti-human c-erbB-2 oncoprotein (HER2/neu) antibody (1:100 in dilution, Dako) at $37^{\circ} \mathrm{C}$ for $40 \mathrm{~min}$ and then with Envision horseradish peroxidase-labeled anti-rabbit IgG polymer (Dako) at $37^{\circ} \mathrm{C}$ for an hour. The reacted 


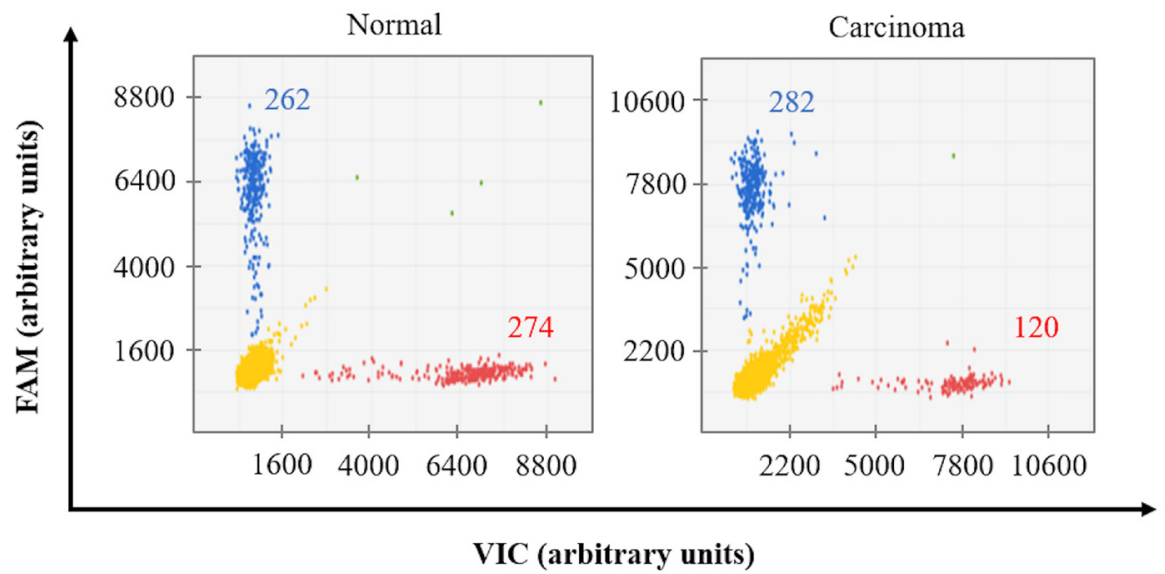

Fig. 1. Two-dimensional scatter plots of the digital PCR assay for detecting ErbB2 copy number aberration in DNA samples obtained from a normal control dog and a dog with mammary carcinoma. ErbB2 was labelled with 6-carboxyfluorescein (FAM), whereas the reference gene in CFA8 was labelled with 4,7,2'-trichloro-7'-phenyl-6-carboxyfluorescein (VIC). Four clusters were identified to be single-positive for FAM (blue) and VIC (red), double-positive (green), and double-negative (yellow). The ratio of blue plot points to red plot points in mammary carcinoma (282 to 120) was much higher than that in the normal control (262 to 274).

products were visualized using 3.3'-diaminobenzidine (Dojindo, Kumamoto, Japan) and $0.03 \% \mathrm{H}_{2} \mathrm{O}_{2}$ in TBS. Counterstaining was conducted with Mayer's hematoxylin. Positive controls were prepared with canine urothelial carcinoma tissue (Supplementary Fig. 1A), which is known to show ErbB2 overexpression according to our previous study [34]. Negative controls were performed by omitting the primary antibody (Supplementary Fig. 1B).

ErbB2 immunoreactivities were quantified based on a guideline proposed in a previous report on canine mammary carcinoma [23]. Interpretation criteria was as follows; a score of 0 denotes no reactivity at all (Fig. 2A), a score of 1+ represents weak and incomplete membrane immunoreactivity in any percentage of cells (Fig. 2B), a score of $2+$ represents strong and complete membrane immunoreactivity (chicken-wire pattern) in $\leq 30 \%$ of cells, or weak or moderate heterogeneous complete membrane immunoreactivity in at least $10 \%$ of cells (Fig. 2C), and a score of $3+$ represents strong, complete, and homogeneous membrane immunoreactivity (chicken-wire pattern) in $>30 \%$ of cells (Fig. 2D). Samples with scores of $0,1+$, and $2+$ were classified as ErbB2 overexpression-negative, and those with a score of $3+$ as ErbB2 overexpression-positive. Although cytoplasmic immunoreactivity was detected in some tumor cells and normal mammary gland epithelial cells, these were not taken into account.

\section{Follow up study}

For survival analyses, information regarding the current status (alive, dead, or lost) till the end of the study (April 7, 2017) was obtained for each mammary carcinoma case based on the medical records or a fax interview with the referring veterinarians. Overall survival (OS) was defined as the interval between surgery and the established cause of death of the animal at the end of the study.

\section{Statistical analyses}

To determine differences in ErbB2:CFA8 ratio among three groups, the Kruskal-Wallis test and post hoc, Dunn's multiple comparison test were performed. Fisher's exact test was used to determine association of CNG and protein overexpression of ErbB2 with histological and clinical characteristics in canine mammary carcinoma cases. Survival curves were generated using the Kaplan-Meier method, and they were compared using the log-rank test. These statistical analyses were performed using Prism software, version 8.1.1 (Graph Pad Software, San Diego, CA, USA). $P<0.05$ was considered to be statistically significant.

\section{RESULTS}

\section{ErbB2 copy number in canine mammary gland tissues}

The median ErbB2:CFA8 ratios (range) in the normal controls, mammary adenoma, and mammary carcinoma were 0.88 (0.69-0.98), $1.00(0.61-1.18)$, and $1.10(0.61-2.35)$, respectively (Fig. 3). The ratio of ErbB2:CFA8 in the mammary carcinoma cases was significantly higher than the normal controls $(P=0.0068)$ but was moderately higher than the mammary adenoma cases (Fig. 3). There was no significant difference in ratio between the normal control and the mammary adenoma cases. To determine a universal threshold of ErbB2 CNG in mammary gland tissues, the mean +3 standard deviation of the ErbB2:CFA8 ratio in the normal controls was calculated and was found to be 1.12. Thus, ErbB2:CFA8 ratio $>1.12$ was defined as the universal threshold. Based on the threshold value, ErbB2 CNG was detected in 14/34 (41\%) mammary carcinoma and 2/14 (14\%) mammary adenoma cases (Table 1). No ErbB2 CNG was detected in the normal controls. 


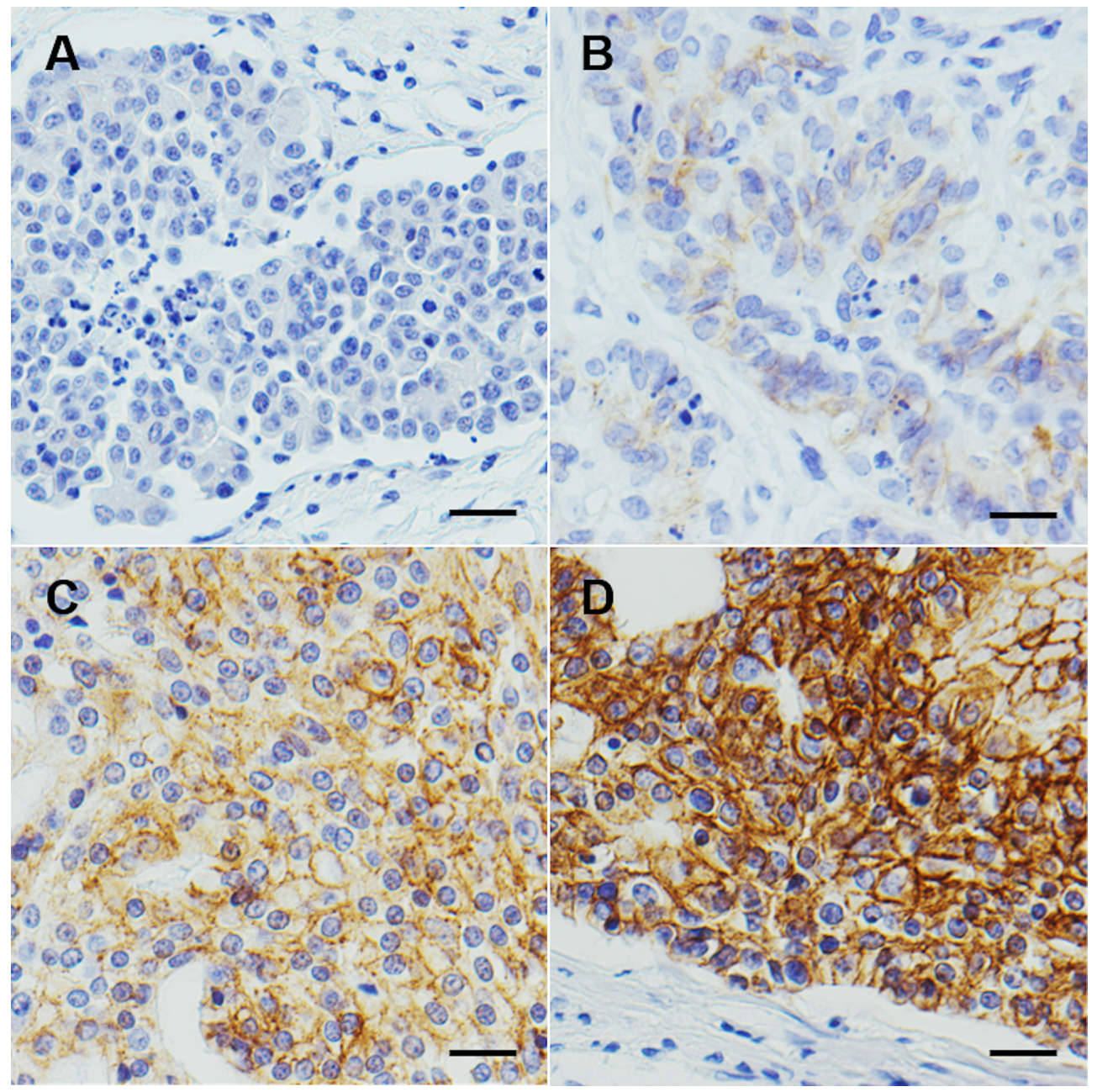

Fig. 2. Immunohistochemistry for ErbB2 in canine mammary gland tissues. No immunoreactivity in the neoplastic cells was scored as 0 (A). Weak and incomplete membrane immunoreactivity in the neoplastic cells was scored as $1+(B)$. Strong and complete membrane immunoreactivity in $\leq 30 \%$ of the neoplastic cells was scored as $2+(\mathrm{C})$. Strong, complete, and homogeneous membrane immunoreactivity (chicken-wire pattern) in $>30 \%$ of the neoplastic cells was scored as 3+ (D). Counter-stained with Mayer's haematoxylin. Bars $=25 \mu \mathrm{m}$.

\section{ErbB2 protein expression in canine mammary gland tissues}

ErbB2 immunoreactivity in each sample is listed in Supplementary Table 1. In the normal controls, 7/8 (88\%) samples were scored as 0 , and the remaining sample (13\%) was scored as $1+$. In the mammary adenoma, $2 / 14(14 \%)$ samples were scored as 0 , $10 / 14(71 \%)$ were scored as $1+$, and $2 / 14(14 \%)$ were scored as $2+$. All samples of the normal controls and mammary adenoma were classified as ErbB2 protein overexpression-negative. In the mammary carcinoma, 13/34 (38\%) samples were scored as 0 , $12 / 34(35 \%)$ were scored as 1+, 6/34 (18\%) were scored as 2+, and 3/34 $(9 \%)$ were scored as $3+$. ErbB2 protein overexpression was observed in $3 / 34(9 \%)$ of mammary carcinomas.

ErbB2 CNG was detected in 2/3 (67\%) mammary carcinoma cases with ErbB2 protein overexpression. On the other hand, ErbB2 overexpression was observed in 2/14 (14\%) mammary carcinoma cases with ErbB2 CNG. There was no significant association between CNG and protein overexpression of ErbB2 (Table 2).

\section{Association of ErbB2 CNG and protein overexpression with histological and clinical characteristics in dogs with mammary carcinoma}

There was no significant association of the ErbB2 CNG with histological and clinical characteristics, such as histological grade, tumor size, lymph node involvement, distant metastasis, and clinical stage in the mammary carcinoma cases (Table 3). However, the $\operatorname{ErbB} 2 \mathrm{CNG}$ tended to be associated with large tumor size $(P=0.1157)$ and lymph node involvement $(P=0.1345)$. Distant metastasis was observed only in the cases with ErbB2 CNG. There was no significant association of the ErbB2 protein overexpression with histological and clinical characteristics in the mammary carcinoma cases (Table 3).

\section{Impact of ErbB2 CNG and protein overexpression on survival in dogs with mammary carcinoma}

All of the mammary carcinoma cases were used for survival analyses. These included 14 cases with ErbB2 CNG and 20 without 
Table 1. Copy number gain and protein overexpression of ErbB2 in canine mammary gland tissues

\begin{tabular}{lllllll}
\hline \multirow{2}{*}{ Sample } & \multirow{2}{*}{$n$} & \multicolumn{2}{c}{ Copy number gain } & & Protein overexpression \\
\cline { 3 - 4 } & & Positive & Negative & & Positive & Negative \\
\hline Normal & 11 & $0(0 \%)$ & $11(100 \%)$ & & $0(0 \%)$ & $11(100 \%)$ \\
Adenoma & 14 & $2(14 \%)$ & $12(86 \%)$ & & $0(0 \%)$ & $14(100 \%)$ \\
Carcinoma & 34 & $14(41 \%)$ & $20(59 \%)$ & & $3(9 \%)$ & $31(91 \%)$ \\
\hline
\end{tabular}

Data are presented as the number of cases involved in the study.

Table 2. Relationship between copy number gain and protein overexpression of ErbB2 in dogs with mammary carcinoma

\begin{tabular}{cccc}
\hline & \multicolumn{2}{c}{ Protein overexpression } & \\
\cline { 2 - 3 } & $\begin{array}{c}\text { Positive } \\
(n=3)\end{array}$ & $\begin{array}{c}\text { Negative } \\
(n=31)\end{array}$ & $P$ \\
\hline Copy number gain & & & \\
Positive $(n=14)$ & 2 & 12 & 0.5555 \\
Negative $(n=20)$ & 1 & 19 & \\
\hline
\end{tabular}

Data are presented as the number of cases involved in the study.

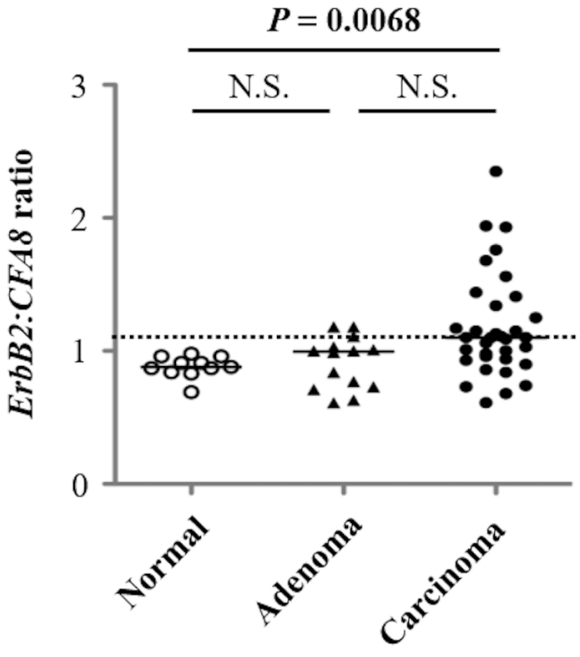

Fig. 3. ErbB2:CFA8 ratios in canine mammary gland tissues of normal $(n=11)$, adenoma $(n=14)$, and carcinoma $(n=34)$. Horizontal lines indicate the medians. The dotted line indicates a universal threshold $(>1.12)$ for detecting ErbB2 copy number gain. N.S., not significant.

Table 3. Association of copy number gain and protein overexpression of ErbB2 with histological and clinical characteristics in dogs with mammary carcinoma

\begin{tabular}{|c|c|c|c|c|c|c|}
\hline & \multicolumn{2}{|c|}{ Copy number gain } & \multirow{2}{*}{$P$} & \multicolumn{2}{|c|}{ Protein overexpression } & \multirow{2}{*}{$P$} \\
\hline & Positive & Negative & & Positive & Negative & \\
\hline \multicolumn{7}{|l|}{$\overline{\text { Age }}$} \\
\hline$\leq$ Median & 5 & 13 & 0.1625 & 1 & 17 & 0.5909 \\
\hline$>$ Median & 9 & 7 & & 2 & 14 & \\
\hline \multicolumn{7}{|l|}{ Neutered status } \\
\hline Intact & 9 & 12 & 1.0000 & 2 & 19 & 1.0000 \\
\hline Spayed & 5 & 8 & & 1 & 12 & \\
\hline \multicolumn{7}{|c|}{ Histological grade } \\
\hline I, II & 12 & 16 & 1.0000 & 2 & 26 & 0.4525 \\
\hline III & 2 & 4 & & 1 & 5 & \\
\hline \multicolumn{7}{|l|}{ Tumor size } \\
\hline $\mathrm{T} 1, \mathrm{~T} 2$ & 8 & 17 & 0.1157 & 1 & 24 & 0.1644 \\
\hline $\mathrm{T} 3$ & 6 & 3 & & 2 & 7 & \\
\hline \multicolumn{7}{|c|}{ Lymph node involvement } \\
\hline No & 7 & 16 & 0.1345 & 1 & 22 & 0.2390 \\
\hline $\mathrm{N}+$ & 7 & 4 & & 2 & 9 & \\
\hline \multicolumn{7}{|c|}{ Distant metastasis } \\
\hline M0 & 12 & 20 & 0.1622 & 2 & 30 & 0.1711 \\
\hline $\mathrm{M}+$ & 2 & 0 & & 1 & 1 & \\
\hline \multicolumn{7}{|l|}{ Clinical stage } \\
\hline I, II, III & 8 & 15 & 0.4575 & 1 & 22 & 0.2390 \\
\hline IV, $\mathrm{V}$ & 6 & 5 & & 2 & 9 & \\
\hline \multicolumn{7}{|c|}{ Postoperative chemotherapy } \\
\hline Yes & 5 & 6 & 1.0000 & 2 & 9 & 0.2390 \\
\hline No & 9 & 14 & & 1 & 22 & \\
\hline
\end{tabular}

Data are presented as the number of cases involved in the study.

ErbB2 CNG. There was no significant difference in age and neutered status between the two groups (Table 3). During the study, 21/34 mammary carcinoma cases died. The dead dogs included 10 cases with ErbB2 CNG and 11 without ErbB2 CNG. The median OS in the cases with and without ErbB2 CNG was 243 days (range, 79-711 days) and 515 days (range, 11-2,008 days), respectively. The OS in the cases with ErbB2 CNG was significantly shorter than that in the cases without $\operatorname{ErbB} 2 \mathrm{CNG}(P=0.0276$; Fig. 4A). 
A - Without copy number gain $(n=20)$

.... With copy number gain $(n=14)$

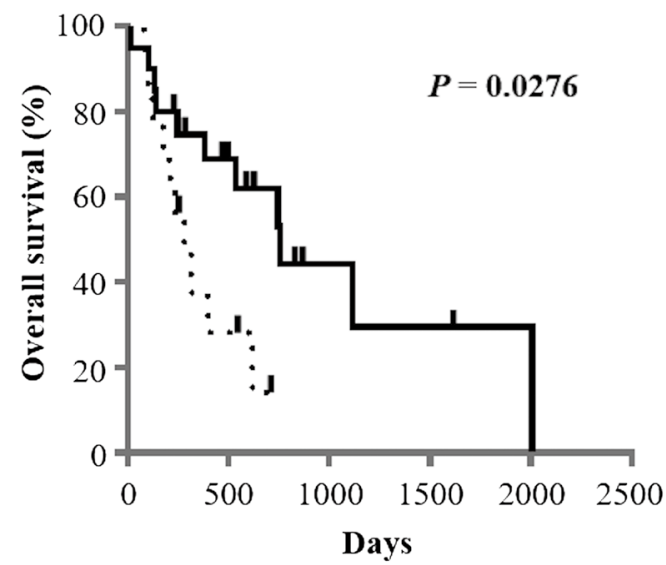

B - Without protein overexpression $(n=31)$

... With protein overexpression $(n=3)$

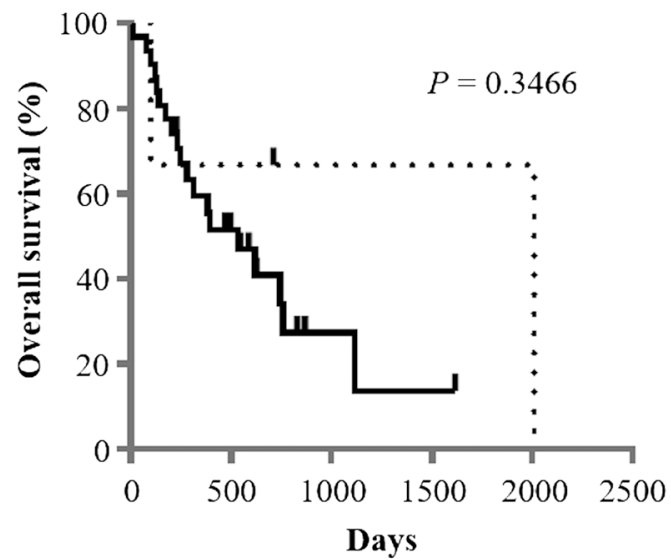

Fig. 4. Kaplan-Meier curves of overall survival in canine mammary carcinoma cases based on copy number gain (A) and protein overexpression (B) of ErbB2. Black symbols indicate censored cases.

Three cases with ErbB2 protein overexpression and 31 without ErbB2 protein overexpression were included in survival analysis. There was no significant difference in age and neutered status between the two groups (Table 3). During the study, 2 cases with ErbB2 protein overexpression and 19 without ErbB2 protein overexpression died. The median OS in the cases with and without ErbB2 protein overexpression was 711 days (range, 99-2,008 days) and 313 days (range, 11-1,615 days), respectively. There was no significant difference in the OS between the two groups $(P=0.3466$; Fig. 4B).

\section{DISCUSSION}

In this study, we found that ErbB2:CFA8 ratios were significantly higher in the canine mammary carcinoma cases than in the normal controls. Based on our established threshold, $E r b B 2 \mathrm{CNG}$ was detected in $41 \%$ of the mammary carcinoma cases. However, the prevalence of $E r b B 2 C N G$ was higher than that of ErbB2 protein overexpression (9\%) in the same mammary carcinoma cases. There was no evidence of ErbB2 protein overexpression in $86 \%$ of the mammary carcinoma cases with ErbB2 CNG, suggesting that just because there is detection of ErbB2 CNG, doesn't mean this will translate to protein overexpression. Analysis of ErbB2 mRNA expression in canine mammary carcinoma might help to explain the discrepancy between CNG and protein overexpression results. Unfortunately, however, mRNA samples of the canine mammary carcinoma were not available due to the retrospective design of the study. On the other hand, ErbB2 CNG was detected in $67 \%$ of the mammary carcinoma cases with ErbB2 protein overexpression. This finding suggests that ErbB2 protein overexpression in canine mammary carcinoma may be due to not only CNG but also other mechanisms such as transcriptional or post-transcriptional mechanisms. In fact, it is known that ErbB2 protein overexpression is caused by increased transcription through high levels of transcriptional activators, such as action protein 2 and Yin Yang 1 in human breast cancer [2]. Further studies are needed to investigate detailed mechanisms of ErbB2 protein overexpression in canine mammary carcinoma.

The proportion of ErbB2 CNG in canine mammary carcinoma were different between this study (41\%) and previous studies $(0 \%$ and 20\%) $[5,19]$. This may be due to differences in threshold-setting methods and assay systems. In addition, this study showed ErbB2 protein overexpression in 9\% of canine mammary carcinoma, however, the proportion was lower than that in previous studies (18-48\%) [10,13, 19, 26, 29]. This discrepancy is, in part, related to variations in evaluation systems. For example, a score of $3+$ was considered protein overexpression in this study, whereas scores of $2+$ and $3+$ were considered protein overexpression in the previous studies $[10,13]$. The difference in methods between studies hamper any definitive conclusions on the ErbB2 expression in canine mammary carcinoma. To standardize the ErbB2 immunohistochemistry in canine mammary carcinoma, Pena et al. (2014) have proposed a guideline [23], following ErbB2 testing in human breast cancer [35]. Therefore, we used the recommended guideline.

Human breast cancer patients with $\mathrm{CNG}$ as well as protein overexpression of ErbB2 have shown poor prognosis [4, 8, 30, 31]. As in humans, the presence of $E r b B 2 \mathrm{CNG}$ in the canine mammary carcinoma cases was significantly associated with the shorter $\mathrm{OS}$, suggesting that $\operatorname{ErbB} 2 \mathrm{CNG}$ is involved in tumor progression. On the other hand, there was no significant association of ErbB2 protein overexpression with the OS in the canine mammary carcinoma cases. Although this may have been due to the low number of cases with ErbB2 protein overexpression, $\operatorname{ErbB} 2 \mathrm{CNG}$ in canine mammary carcinoma may be a more useful prognosis indicator than ErbB2 protein overexpression.

In human breast cancer, $\mathrm{CNG}$ and/or protein overexpression of ErbB2 are important predictors for response to ErbB2targeted therapies, such as those using trastuzumab and lapatinib $[6,7,24,32]$. In this study, we detected CNG and/or protein 
overexpression of ErbB2 in about half of the canine mammary carcinoma cases. Although these abnormalities were not strongly inter-related, there is considerable potential of ErbB2-targeted therapies for canine mammary carcinoma. However, there is no report on clinical trial of ErbB2-targeted therapies for dogs with mammary carcinoma at present. Further studies will be necessary to investigate antitumor effect of ErbB2-targeted therapies on canine mammary carcinoma and predict response to the therapies.

ErbB2 CNG was also detected in 14\% of the canine mammary adenoma cases. However, no ErbB2 protein overexpression was observed in all of the cases. CNG and protein overexpression of ErbB2 in canine mammary adenoma are controversial. Although Martin et al. (2003) have reported that no ErbB2 CNG was detected in two canine mammary adenoma cases [19], the sample size was too small. A previous study has reported no ErbB2 protein overexpression in 22 canine benign mammary tumor cases [9], whereas another study has shown that ErbB2 protein overexpression was observed in 16/32 (50\%) canine benign mammary tumor cases [26]. In human benign breast diseases, ErbB2 CNG has been detected in $6.8 \%$ of patients, and was associated with an increased risk of breast cancer [33]. Thus, the ErbB2 CNG detected in the canine mammary adenoma cases might be associated with the risk of developing carcinoma. Further studies are necessary to investigate the association between ErbB2 CNG and an increased risk of carcinogenesis in canine mammary adenoma.

There were some limitations to this study. First, the sample size in this study was relatively small. ErbB2 overexpression was detected only in 3 dogs. More extensive study will be needed. Second, the median percentages of tumor cells in the adenoma and carcinoma tissues were 30\% (range, $10-90 \%$ ) and 50\% (range, $10-90 \%$ ), respectively (Supplementary Table 1). A large amount of non-tumor cells may have influenced the results of the dPCR assay. Third, histological and clinical characteristics in the mammary carcinoma cases were not unified. There was no significant difference in these characteristics between the cases with ErbB2 CNG and without ErbB2 CNG (Table 3). However, postoperative chemotherapy may have influenced the OS in each case. Application of the dPCR assay to a larger case series with a more standardized post-diagnostic care would help to formalize the apparent association.

The present study suggested that ErbB2 CNG is associated with adverse outcomes in dogs with mammary carcinoma. This finding provides new insights into the molecular pathogenesis of canine mammary carcinoma.

CONFLICT OF INTEREST. The authors have nothing to disclose.

ACKNOWLEDGMENTS. We thank Dr. S. Iwai (Kitasato University) for providing canine normal mammary gland tissues. This study was financially supported by the Grants-in-Aid for Scientific Research (KAKENHI Grant Numbers 16H06208 and 19H00968), fellows of the Japan Society for the Promotion of Science (JSPS), and the Anicom Capital Research Grant (EVOLVE).

\section{REFERENCES}

1. Abdelmegeed, S. M. and Mohammed, S. 2018. Canine mammary tumors as a model for human disease. Oncol. Lett. 15: 8195-8205. [Medline]

2. Allouche, A., Nolens, G., Tancredi, A., Delacroix, L., Mardaga, J., Fridman, V., Winkler, R., Boniver, J., Delvenne, P. and Begon, D. Y. 2008. The combined immunodetection of AP-2alpha and YY1 transcription factors is associated with ERBB2 gene overexpression in primary breast tumors. Breast Cancer Res. 10: R9. [Medline] [CrossRef]

3. Andrade, F. H., Figueiroa, F. C., Bersano, P. R., Bissacot, D. Z. and Rocha, N. S. 2010. Malignant mammary tumor in female dogs: environmental contaminants. Diagn. Pathol. 5: 45. [Medline] [CrossRef]

4. Andrulis, I. L., Bull, S. B., Blackstein, M. E., Sutherland, D., Mak, C., Sidlofsky, S., Pritzker, K. P., Hartwick, R. W., Hanna, W., Lickley, L., Wilkinson, R., Qizilbash, A., Ambus, U., Lipa, M., Weizel, H., Katz, A., Baida, M., Mariz, S., Stoik, G., Dacamara, P., Strongitharm, D., Geddie, W., McCready D., Toronto Breast Cancer Study Group. 1998. neu/erbB-2 amplification identifies a poor-prognosis group of women with nodenegative breast cancer. J. Clin. Oncol. 16: 1340-1349. [Medline] [CrossRef]

5. Beck, J., Hennecke, S., Bornemann-Kolatzki, K., Urnovitz, H. B., Neumann, S., Ströbel, P., Kaup, F. J., Brenig, B. and Schütz, E. 2013. Genome aberrations in canine mammary carcinomas and their detection in cell-free plasma DNA. PLoS One 8: e75485. [Medline] [CrossRef]

6. Blackwell, K. L., Pegram, M. D., Tan-Chiu, E., Schwartzberg, L. S., Arbushites, M. C., Maltzman, J. D., Forster, J. K., Rubin, S. D., Stein, S. H. and Burstein, H. J. 2009. Single-agent lapatinib for HER2-overexpressing advanced or metastatic breast cancer that progressed on first- or secondline trastuzumab-containing regimens. Ann. Oncol. 20: 1026-1031. [Medline] [CrossRef]

7. Burstein, H. J., Storniolo, A. M., Franco, S., Forster, J., Stein, S., Rubin, S., Salazar, V. M. and Blackwell, K. L. 2008. A phase II study of lapatinib monotherapy in chemotherapy-refractory HER2-positive and HER2-negative advanced or metastatic breast cancer. Ann. Oncol. 19: 1068-1074. [Medline] [CrossRef]

8. Carr, J. A., Havstad, S., Zarbo, R. J., Divine, G., Mackowiak, P. and Velanovich, V. 2000. The association of HER-2/neu amplification with breast cancer recurrence. Arch. Surg. 135: 1469-1474. [Medline] [CrossRef]

9. Dutra, A. P., Granja, N. V., Schmitt, F. C. and Cassali, G. D. 2004. c-erbB-2 expression and nuclear pleomorphism in canine mammary tumors. Braz. J. Med. Biol. Res. 37: 1673-1681. [Medline] [CrossRef]

10. Gama, A., Alves, A. and Schmitt, F. 2008. Identification of molecular phenotypes in canine mammary carcinomas with clinical implications: application of the human classification. Virchows Arch. 453: 123-132. [Medline] [CrossRef]

11. Goldschmidt, M., Peña, L., Rasotto, R. and Zappulli, V. 2011. Classification and grading of canine mammary tumors. Vet. Pathol. 48: 117-131. [Medline] [CrossRef]

12. Gutierrez, C. and Schiff, R. 2011. HER2: biology, detection, and clinical implications. Arch. Pathol. Lab. Med. 135: 55-62. [Medline]

13. Im, K. S., Kim, I. H., Kim, N. H., Lim, H. Y., Kim, J. H. and Sur, J. H. 2013. Breed-related differences in altered BRCA1 expression, phenotype and subtype in malignant canine mammary tumors. Vet. J. 195: 366-372. [Medline] [CrossRef]

14. Iqbal, N. and Iqbal, N. 2014. Human epidermal growth factor receptor 2 (HER2) in cancers: overexpression and therapeutic implications. Mol. Biol. Int. 2014: 852748. [Medline] [CrossRef]

15. Ito, C., Nishizuka, S. S., Ishida, K., Uesugi, N., Sugai, T., Tamura, G., Koeda, K. and Sasaki, A. 2017. Analysis of PIK3CA mutations and PI3K 
pathway proteins in advanced gastric cancer. J. Surg. Res. 212: 195-204. [Medline] [CrossRef]

16. Jiang, H., Bai, X., Meng, F., Zhang, C. and Zhang, X. 2014. Evaluation of chromosome 17 polysomy in breast cancer by FISH analysis of whole nuclei, and its clinicopathological significance. Oncol. Lett. 7: 1954-1958. [Medline] [CrossRef]

17. Jimenez, R. E., Wallis, T., Tabasczka, P. and Visscher, D. W. 2000. Determination of Her-2/Neu status in breast carcinoma: comparative analysis of immunohistochemistry and fluorescent in situ hybridization. Mod. Pathol. 13: 37-45. [Medline] [CrossRef]

18. Liu, D., Xiong, H., Ellis, A. E., Northrup, N. C., Rodriguez, C. O. Jr., O’Regan, R. M., Dalton, S. and Zhao, S. 2014. Molecular homology and difference between spontaneous canine mammary cancer and human breast cancer. Cancer Res. 74: 5045-5056. [Medline] [CrossRef]

19. Martin de las Mulas, J., Ordás, J., Millán, Y., Fernández-Soria, V. and Ramón y Cajal, S. 2003. Oncogene HER-2 in canine mammary gland carcinomas: an immunohistochemical and chromogenic in situ hybridization study. Breast Cancer Res. Treat. 80: 363-367. [Medline] [CrossRef]

20. Moe, L. 2001. Population-based incidence of mammary tumours in some dog breeds. J. Reprod. Fertil. Suppl. 57: 439-443. [Medline]

21. Owen, L. N. 1980. TNM classification of tumours in domestic animals, World Health Organization, Geneva.

22. Owens, M. A., Horten, B. C. and Da Silva, M. M. 2004. HER2 amplification ratios by fluorescence in situ hybridization and correlation with immunohistochemistry in a cohort of 6556 breast cancer tissues. Clin. Breast Cancer 5: 63-69. [Medline] [CrossRef]

23. Peña, L., Gama, A., Goldschmidt, M. H., Abadie, J., Benazzi, C., Castagnaro, M., Díez, L., Gärtner, F., Hellmén, E., Kiupel, M., Millán, Y., Miller, M. A., Nguyen, F., Poli, A., Sarli, G., Zappulli, V. and de las Mulas, J. M. 2014. Canine mammary tumors: a review and consensus of standard guidelines on epithelial and myoepithelial phenotype markers, HER2, and hormone receptor assessment using immunohistochemistry. Vet. Pathol. 51: 127-145. [Medline] [CrossRef]

24. Piccart-Gebhart, M. J., Procter, M., Leyland-Jones, B., Goldhirsch, A., Untch, M., Smith, I., Gianni, L., Baselga, J., Bell, R., Jackisch, C., Cameron, D., Dowsett, M., Barrios, C. H., Steger, G., Huang, C. S., Andersson, M., Inbar, M., Lichinitser, M., Láng, I., Nitz, U., Iwata, H., Thomssen, C., Lohrisch, C., Suter, T. M., Rüschoff, J., Suto, T., Greatorex, V., Ward, C., Straehle, C., McFadden, E., Dolci, M. S., Gelber R. D., Herceptin Adjuvant (HERA) Trial Study Team. 2005. Trastuzumab after adjuvant chemotherapy in HER2-positive breast cancer. N. Engl. J. Med. 353: 1659-1672. [Medline] [CrossRef]

25. Raposo, T. P., Arias-Pulido, H., Chaher, N., Fiering, S. N., Argyle, D. J., Prada, J., Pires, I. and Queiroga, F. L. 2017. Comparative aspects of canine and human inflammatory breast cancer. Semin. Oncol. 44: 288-300. [Medline] [CrossRef]

26. Rungsipipat, A., Tateyama, S., Yamaguchi, R., Uchida, K., Miyoshi, N. and Hayashi, T. 1999. Immunohistochemical analysis of c-yes and c-erbB-2 oncogene products and 533 tumor suppressor protein in canine mammary tumors. J. Vet. Med. Sci. 61: 27-32. [Medline] [CrossRef]

27. Rusnak, D. W., Lackey, K., Affleck, K., Wood, E. R., Alligood, K. J., Rhodes, N., Keith, B. R., Murray, D. M., Knight, W. B., Mullin, R. J. and Gilmer, T. M. 2001. The effects of the novel, reversible epidermal growth factor receptor/ErbB-2 tyrosine kinase inhibitor, GW2016, on the growth of human normal and tumor-derived cell lines in vitro and in vivo. Mol. Cancer Ther. 1: 85-94. [Medline]

28. Sakai, K., Maeda, S., Saeki, K., Yoshitake, R., Goto-Koshino, Y., Nakagawa, T., Nishimura, R., Yonezawa, T. and Matsuki, N. 2020. ErbB2 copy number aberration in canine urothelial carcinoma detected by a digital polymerase chain reaction assay. Vet. Pathol. 57: 56-65. [Medline] [CrossRef]

29. Sassi, F., Benazzi, C., Castellani, G. and Sarli, G. 2010. Molecular-based tumour subtypes of canine mammary carcinomas assessed by immunohistochemistry. BMC Vet. Res. 6: 5. [Medline] [CrossRef]

30. Sjögren, S., Inganäs, M., Lindgren, A., Holmberg, L. and Bergh, J. 1998. Prognostic and predictive value of c-erbB-2 overexpression in primary breast cancer, alone and in combination with other prognostic markers. J. Clin. Oncol. 16: 462-469. [Medline] [CrossRef]

31. Slamon, D. J., Clark, G. M., Wong, S. G., Levin, W. J., Ullrich, A. and McGuire, W. L. 1987. Human breast cancer: correlation of relapse and survival with amplification of the HER-2/neu oncogene. Science 235: 177-182. [Medline] [CrossRef]

32. Smith, I., Procter, M., Gelber, R. D., Guillaume, S., Feyereislova, A., Dowsett, M., Goldhirsch, A., Untch, M., Mariani, G., Baselga, J., Kaufmann, M., Cameron, D., Bell, R., Bergh, J., Coleman, R., Wardley, A., Harbeck, N., Lopez, R. I., Mallmann, P., Gelmon, K., Wilcken, N., Wist, E., Sánchez Rovira, P., Piccart-Gebhart M. J., HERA study team. 2007. 2-year follow-up of trastuzumab after adjuvant chemotherapy in HER2-positive breast cancer: a randomised controlled trial. Lancet 369: 29-36. [Medline] [CrossRef]

33. Stark, A., Hulka, B. S., Joens, S., Novotny, D., Thor, A. D., Wold, L. E., Schell, M. J., Melton, L. J. 3rd., Liu, E. T. and Conway, K. 2000. HER-2/ neu amplification in benign breast disease and the risk of subsequent breast cancer. J. Clin. Oncol. 18: 267-274. [Medline] [CrossRef]

34. Tsuboi, M., Sakai, K., Maeda, S., Chambers, J. K., Yonezawa, T., Matsuki, N., Uchida, K. and Nakayama, H. 2019. Assessment of HER2 expression in canine urothelial carcinoma of the urinary bladder. Vet. Pathol. 56: 369-376. [Medline] [CrossRef]

35. Wolff, A. C., Hammond, M. E., Schwartz, J. N., Hagerty, K. L., Allred, D. C., Cote, R. J., Dowsett, M., Fitzgibbons, P. L., Hanna, W. M., Langer, A., McShane, L. M., Paik, S., Pegram, M. D., Perez, E. A., Press, M. F., Rhodes, A., Sturgeon, C., Taube, S. E., Tubbs, R., Vance, G. H., van de Vijver, M., Wheeler, T. M., Hayes D. F., American Society of Clinical Oncology College of American Pathologists. 2007. American Society of Clinical Oncology/College of American Pathologists guideline recommendations for human epidermal growth factor receptor 2 testing in breast cancer. J. Clin. Oncol. 25: 118-145. [Medline] [CrossRef]

36. Wood, E. R., Truesdale, A. T., McDonald, O. B., Yuan, D., Hassell, A., Dickerson, S. H., Ellis, B., Pennisi, C., Horne, E., Lackey, K., Alligood, K. J., Rusnak, D. W., Gilmer, T. M. and Shewchuk, L. 2004. A unique structure for epidermal growth factor receptor bound to GW572016 (Lapatinib): relationships among protein conformation, inhibitor off-rate, and receptor activity in tumor cells. Cancer Res. 64: 6652-6659. [Medline] [CrossRef] 